УДК УДК 821.163.41.09 Веселиновић, Јанко https://doi.org/10.18485/godisnjak.2016.11.17

Владимир Д. Јанковић* Београд
Оригинални научни рад

Примљен: 05. 10. 2016.

Прихваћен: 20. 10. 2016.

\title{
ПОБРАТИМСТВО КАО КРИПТОГРАМСКИ КОД У ПРИПОВЕТКИ ВЕЧНОСТ ЈАНКА ВЕСЕЛИНОВИЋА
}

\begin{abstract}
У овом раду ће бити речи о приповетки Вечност Јанка Веселиновића, коју ћемо покушати да сагледамо из новог угла. Акценат истраживања биће не само на ономе што се експлицитно приказује већ и на ономе што се прећуткује. Побратимство као основни мотив овог дела представља својеврсни пример криптограма чијим тумачењем се долази до скривених значења. Аутор рада нуди један од могућих видова тумачења неисцрпне грађе који може послужити као полазиште будућих истраживања ове теме.
\end{abstract}

Кључне речи: мотив побратимства, криптограм, идентитет, јавно и приватно, реалистичка приповетка.

Приповетка Вечност је реалистичка приповетка фолклорне оријентације, објављена у издању Велимира Валможића 1894. године. Аутора приповетке Јанка Веселиновића већина критичара представља као идиличног реалисту - традиционалисту, идеализатора села и патријархалних вредности, са оптимистичким виђењем живота у ком добро побеђује зло, као писца чији су ликови конструисани изразито позитивно са негативним антиподом.Уколико задремо дубље у свет јунака Веселиновићеве прозе, доћи ћемо до закључка да патријархална средина у његовим делима може бити и репресивна. То је свет строге хијерархије и ауторитарности, а

"vlajco.cb@gmail.com 
јунаци живе животе какви су им наметнути обичајем и патријархалним устројством.

Изложена запажања важе и за приповетку Вечност. Међутим, ово књижевно дело одступа од осталих прозних дела Јанка Веселиновића. Кроз даље истраживање изложићемо став како је писац овог дела хтео рећи нешто о својим јунацима што се у српској култури онога времена није могло рећи. Тврдња на самом почетку може наићи на оштру реакцију; уколико узимамо у обзир биографске податке писца (Деретић 2004: 816817). ${ }^{1}$ Поћи ћемо од става да аутор није могао бити упознат са савременим концепцијама идентитета, што не значи да својом уметничком интуицијом није могао да приповеда о таквим концептима.

Сам почетак дела је бајковит, у духу поетског реализма: „Била тако два суседа. Живели су лепо као браћа" (Веселиновић 1927: 140). Пријатељство, како сазнајемо, по принципу наслеђа прелази са очева на синове - Илију и Бранка (,па се и деца пазила и оцеви”) и постаје узорито за окружење:

- Ако је рад, на њиви су; ако је прело, на прелу су; ако ли свадба, на свадби су. Свагда су заједно и све загрљени. И куд ходе они певају, певају као две лепе девојке. Кршна деца (...).

Родитељи су своју децу корели њима двојицом.

- Што се свађате, што се ружите? - Погледајте Бранка и Илију, па се постидите! Ни браћа се онако не пазе! (Веселиновић 1927: 140)

Изузетност односа захтевао је неки вид установљења - чин братимљења - и то ће се остварити на Бранков предлог и уз благослов родитеља. На путу до цркве дивљење људи се наставља:

- Боже! Дај им среће! ...

- Боже! Дај им здравља! ... (Веселиновић 1927: 141)

Ове секвенце ће бити од изузетног значаја и можда потирати једну од тврдњи које ће бити изложене у наставку рада. Не само да је средина одобравала и благосиљала пријатељство Илије и Бранка, већ је и стари свештеник задивљен топлином и љубављу која исијава из двојице младића: „Попа је гледао у запламљене образе Илијине; гледао је у жар очију Бранкових" (Веселиновић 1927: 141).

Посматрано из психолошке перспективе, манифестације на телима побратима су јасне ознаке „више емоције” која превазилази оквире при-

\footnotetext{
${ }^{1}$ Јанко Веселиновић рођен је у селу Црнобарски Салаш, као син свештеника; и сам је требало да буде свештеник, али је упркос родитељским жељама уписао учитељску школу. Кратка биографска информација могла би представљати камен спотицања за наставак анализе мотива побратимства као криптограмског кода који декодирањем даје „провокативан закључак”, али фокус проучавања биће на самом књижевном тексту, независно од личности писца.
} 
јатељско-породичног. Све је сведено на мали број свима познатих физиолошких манифестација које су супституција за дубоко лично осећање и интимнији говор. Цео чин братимљења одаје утисак везивања, али не у смислу духовног сродства (мада је то једина могућност за јунаке да се споје; и за приповедача да се изрази), већ сједињења (в. Барјактаревић 1992: 159), ${ }^{2}$ што се такође може уочити у тексту:

Када су изашли из цркве, осећали су нешто узвишено у души; осећали су милу везу, која је као нека света рука, везивала срца њихова.

Очима пуним суза погледаше се и пружише руке један другома (Веселиновић 1927: 141).

Описане реакције и осећаји наликују на оне које имају младенци након венчања - руменило, сјај у очима, пријатан осећај у грудима, сузе радоснице и за крај пружају руке један другом, а не руку како је очекивано у традиционално „мушко - мушком” пријатељству. Затим, услеђује завет попут оног венчаног, али још јачег везивног ефекта:

- Побратиме! Твој сам до гроба! - рече Бранко.

- Побратиме! И до гробља, и у гробу, твој сам! - рече Илија (Веселиновић 1927 : 142).

Изложено се може оспорити, јер Бранко и Илија један другог називају „побратиме”. Да ли ова именица не може имати никакву другу конотацију до оне намењене/додељене или просто „није био ред”, а ни постојала могућност за други начин ословљавања. Уколико направимо поређење са библијском Пјесмом над пјесмама, уочавамо да лирски субјект своју драгану назива „сестром”. Усмерени смо на сам текст као доказ, стога су изложене тврдње и те како поткрепљујуће.

Дакле, путем сажетих информација датих у тексту сазнајемо да је однос два пријатеља превазилазио братске/породичне оквире. Потребно је, пре наставка, истраживања саме приче и релације два побратима, скренути пажњу на ауторов однос према тексту и јунацима. Интерпункција, штуре информације и честе ретиценције указују на одређени вид ограђивања писца од информација изложених у тексту. „Приповедање донекле” је карактеристична реалистичка стратегија (в. Вукићевић 2011: 25-46).

У другом делу „докази” као да иду у прилог „провокативној теорији” аутора рада. Посебно ћемо истаћи да се тумачење изводи на основу

${ }^{2}$ М. Барјактаревић у Прилозима за кюижевност, језик, историју и фолклор у тексту Неки ранији облици ,сродства” код нас наводи следећу тврдњу: „На тај начин (духовним орођавањем) се надокнађивало понешто од онога што се иначе у неразвијеним условима није имало". 
„опипљивих доказа” у самом тексту Веселиновићевог дела. У наставку сазнајемо:

И дотле се нису раздвајали један од другога, али од тог дана беху вазда заједно. Јели су један залогај и спавали на једној постељи; рука једног била је узглавље другом. Па и то им мало!... Да су могли, носили би једну капу и једну кошуљу!... (Веселиновић 1927: 142).

Кључно питање које се поставља пред проучаваоца текста (или опрезнијег читаоца) јесте - Зашто два побратима живе заједно? Зашто спавају на истој постељи и зашто је рука једног била узглавље другом? Уколико се пажња усмери на саму интерпункцију (!...), увиђа се да је цео текст састављен по принципу криптограма, али мали број информација је довољан за комплетирање „смисаоности и истинитости” која стоји иза текста - дешифровањем „скривеног писма” долази се до читљивих „истина” у тексту. Познато је да Јанко Веселиновић у својим делима опис интимног „скупља”, третирајући га као „неприличну тему” - еротско се пригушује, смешта у окоштале фразе, и естетска игра се завршава. У наставку овог дела приповетке још једна реченица потврђује закључак - „Сутрадан, Бранко се диже с колима у шуму да дрва дотера... Илија оста код куће да провери нешто ограде, што беше посрнула...” (Веселиновић 1927: 142).

Како традиционални обичаји и логичност опхођења у друштвеним оквирима Веселиновићевих књижевних дела налажу, Илија и Бранко ће се повезати заветом деверовања.

- Побратиме! Бабо рече да ће ме женити.

- И мене мој - рече Бранко.

- Ти ћеш деверити.

- То се зна!... Ја ћу бити најсрећнији онда, када твоју младу за руку поведем. Знаш ли ти, побратиме, да ти ја не би ни опростио када би ти другог побратио!

- Ја то не би ни чинио! - рече Илија.

- И да умрем, па када ме ти не би позва'о у деверство, ја ти не би опростио!

- рече Бранко.

- Бог с тобом!... Шта то говориш?

Бранко се насмеја.

- Велим: било би ми и мртвом тешко!... Па, деде, коју ћемо цуру за те? - окрете разговор Бранко... (Веселиновић 1927: 142).

Један од честих мотива књижевних дела Јанка Веселиновића је слутња и њен антиципацијски потенцијал. Аутор свесно приликом првог заветовања (братимљења) наговештава да смрт није никаква препрека и да јунаци могу остати „везани” и након живота. Опет, приликом другог заветовања (деверства) - Илијин говор уводи црну мисао и антиципацију 
догађаја који ће уследити. Ситуација са изразито хипотетичким садржајем постаје реализована. Под мистериозним околностима Бранко страда у шуми. Упечатљив детаљ у тексту је опис његовог тела са „скоро одсеченом главом".

Уколико побратимство посматрамо као етнолошку категорију, познато је да се за свеца заштитника, тј. свеца покровитеља духовног сродства узима свети Јован Крститељ. Није ли логично повезати са Веселиновићевом причом, ону из хришћанске традиције о обезглављивању светог Јована? Такође, за велики грех сматрало се прекорачење установљене норме да духовни сродници пређу границу и ступе у интимне релације. Стога, цела епизода о убиству Бранка одједном престаје да буде обавијена велом тајне. Други део приповетке завршава се реченицом - „Нико живи не знаде казати ко је убио Бранка!...” Аутор и ову реченицу завршава специфичном интерпункцијом - нешто се прећутало. Али касније, у шестом поглављу дела, повампирени Бранко ће изговорити следеће - „Што пролисте невину крв!...” Закључак је да извршитељ није било једно лице - убица, већ их је било више. Хипотетички заплет којим се приближавамо опасној граници учитавања могао би да гласи - неколико људи из средина нису били благонаклони према двојици побратима, па су стога решили да казне прекорачење строго утврђеног начина функционисања у патријархалном друштву.

У реалистичким текстовима лако се може реконструисати друштвено неподобан модел одступања и њему надређен патријархални код (Барјактаревић 1992: 152). ${ }^{3}$ Изложена тврдња може се окарактерисати као тачна уколико је читање књижевног дела било конотативно (симболично - нпр. јунак умире јер се огрешио о строг систем табу-прописа), а нетачна уколико је читање денотативно (референтно - нпр. јунак умире пуким случајем - нашао се на погрешном месту у погрешно време).

Посебно морамо истаћи наставак приповетке у коме се живот наставља даље за све, али не и за Илију. Он на својствен начин и кроз дужи временски период пролази кроз патњу. Он проживљава Бранкову смрт другачије од осталих. Поступком градације истиче се Илијин однос према побратимовој смрти и однос родитеља према смрти сина. Истакнуто је то да родитељи, који највише пате за својим дететом, туговаме, na се u примирише, док рана на Илијином срцу никако да зацели.

${ }^{3}$ Било какво прекорачење интимних граница у духовном сродству сматра се у нашем народу за много тежи грех него када је крвно сродство у питању или када је по среди сродство по браку. Православна црква је девера (такође) рачунала за сродство које је било сметња за склапање брака или било какве интимније приче. 
И прође година дана... Оптужени су лежали у тамници, али ствар се не може расветлити...

Родитељи Бранкови туговаше, па се и примирише. Рана је ту, на срцу; она тиња, боли; али ето, живе... Право веле: не вади душу мука, него суђен сат..

Међутим родитељи Илијини већ другачије гледаху на свога сина. Мајци је требала одмена а оцу послуга, а обома радости. Жеља је човечија најнеситија ала. Све, што има на свету, она би прождрала и опет јој мало!...

Њима не беше доста што им је син жив, - они су желели снају, па затим унука. И почеше, онако изоколо, наговештавати Илији жеље своје... (Веселиновић 1927: 144) Почиње Илијина драма, како лична, тако и сукоб са околином која не може да разуме и оправда толику везаност за мртвог побратима.

Како му то поменуше, он проли сузе.

- Зар да заборавим побратима?

И тог дана нит' је јео ни пио. Бежао је од сваког живог створа...

Али капља камен дуби!...Дан по дан, једно те једно... Он је већ могао да слуша о својој женидби. А када му, једног дана, и отац и мати побратимови рекоше да му се ваља женити, он саже главу, као во у јарам (Веселиновић 1927: 142).

Јавне и приватне намере увек су сукобљене у делима Јанка Веселиновића, али прве увек превагну. Стога, млади Илија прихвата наметнути идентитет (проћи иницјацију и постати муж), попушта под пресијом, и спроводи у дело породична и друштвена очекивања.

Догађаји који следе спадају у домен фантастичног и фолклорног. Илија прихвата правила нове животне улоге, али не одступа од задатог обећања. Када га отац упита кога ће деверити, он без трунке сумње и размишљања одговара - Ja, бабо, имам побратима. Одлази на гробље и води концизни неочекивано-очекиван разговор са мртвим Бранком.

- Ја се женим...

- Нек ти је са срећом! - одговори глас из гроба.

- Али сам на речи!...

- Томе сам се и нада'о!...

- Треба девер.

- Ја сам девер!

- Свадба је у недељу.

- Добро.

- 'Оћемо ли те чекати?

- Не... када буде време, ја ћу бити тамо!...

'Вла ти, што ме ниси заборавио! (Веселиновић 1927: 145).

Бранко је у лиминалној фази - завет који је дао побратиму га не искључује из активности „живог света”, стога његов прелазак „на другу страну" није потпун. Два побратима спајају љубав и два завета (побратимски и деверски).

Од изузетне је важности скренути пажњу на четврти део приповетке. Приметно је одсуство многих очекиваних елемената. Цео текст је уздржан 
и недоречен у самом приповедању и описима. Невеста се тек помиње, сватови су као позадински декор, а главни актер сцене је повампирени младић који код присутних људи не изазива очекивану рекацију појавивши се на раскршћу. Део дијалога између сватова, једино одступа од „чудно смирене реакције” на појаву мртвог међу живима. ,,- Грешна душа Илији што га је диз'о!... - А... заверили се, брате!...” (Веселиновић 1927: 147).

Фокус свадбене сцене је, опет, на односу Илије и Бранка. У њиховом опхођењу не постоји фактор сумње и недоумице, па се у том маниру и овај део завршава.

- Збогом, побратиме!

- Зар оде, побратиме?

- Идем... Него, сети ме се, драги побро, па дођи!

- Доћи ћу, побратиме! - рече Илија. (Веселиновић 1927: 148)

Након венчања умрли побратим подсећа живог на задато обећање путем сна. По принципу реципроцитета Илија узвраћа посету Бранку и одлази у загробни живот у посету побратиму. Приликом одласка на гробље, занимљиво је да аутор у опхођење јунака поново убацује ефекат слутње. Млади Илија има осећај како се више никада неће вратити, што се касније и потврђује. Елементи фантастике и митског слоја неће бити предмет овога рада, али је потребно нагласити да је Вечност дело које одводи проучаваоца/читаоца у мноштво праваца, стога је неисцрпни извор за проучавање.

Незаобилазни део текста је Илијин говор о љубави, који је по много чему интересантан.

Само љубав је над свим! Она је равна Господу и сину његовом! Шира је од небеског покрова, дубља од бездана, јача од највеће силе! То је највећа сила на свету. Она везује дете и мајку, везује листак с листом, травку са травком, човека с човеком... Њена моћ - моћ је божја, она је чедо божје!... Упамти то, побратиме!... (Веселиновић 1927: 153).

Неколико цитираних реченица постављају мноштво питања. Како је могуће да се у једном реалистичком тексту излаже овакво виђење љубави? Бранко помиње различите варијанте везивања, али оно што посебно упада у очи је љубав „човека с човеком”, а не човека с женом.

Уколико укључимо фактор времена у ком је дело настало, израз човек односи се само на особу мушког пола. Јер, некада у патријархалном свету реч - човек (или множина - људи) била је резервисана само за мушкарце. Наш језик (и они који се њиме служе) када је у питању ова именица и даље чува патријархат. Мушкарац и жена су хипоними у односу на појам „човек/људи” - никада се не каже да су сви људи „сестре”, 
већ увек „браћа”. Када се користимо неодређеном заменицом за људско биће, опет ћемо казати он (човек) - a „човек” је реч која се у нашем језику одвећ често користи за мушкарца (и данас се може чути „човек и жена” у значењу „мушкарац и жена”) (Ћопић 2008: 221-222).

Још једно питање се намеће - Зашто оваква „беседа” излази из уста мртвог јунака? Даљим истраживањем текста ћемо видети да аутор на различите начине измешта причу, приповедача, јунаке и ситуацију из „овог времена” и „сада”. Измештеност се уочава на самом почетку (Била тако два суседа...), а затим, како ћемо у даљем тексту увидети, и на крају. Прича о два побратима има „необичан карактер”, па ју је потребно изместити просторно и временски, а затим и приповедачки (,...слатка су сећања на детињство, кад су нас оваквим лепим причама успављивали...”). Стога, није чудно да се емотивно и естетски најважнији детаљ дела смешта у онострану сферу - изговара га покојник.

Говор о љубави је чврста нит која је повезана са насловом дела. Зашто је аутор за наслов дела узео именицу вечност? Вечност је, дакле, нешто без краја и почетка, без трајања и јасне границе. Критичари, углавном, Јанка Веселиновића представљају као традиционалисту, стриктно усмереног идеализатора села и патријархалних вредности са оптимистичким виђењем живота. Али текст овог дела потврђује тезу малобројних да је дело Веселиновића у тумачењима доста симплификовано. Не само да је наслов дела у потпуном сагласју са целокупном радњом (од почетка до краја), јер временска баријера је прекинута, као и граница између живота и смрти; а посебно се истиче моћ љубави која је у стању да покида установљене оквире - крше се наметнути табуи и норме, превазилази се просторна и временска димензија. Двојица главних јунака у животу се спајају, не под девизом „док нас смрт не растави”, већ и у смрти припадају један другом („И до гробља, и у гробу, твој сам!”). Смрт Бранкова није препрека за још један вид спајања - деверство, а након тога посета живог мртвом и путовање Илије кроз смрт и време. Мотив који води оба јунака је љубав - волети ради љубави, а не ради обичаја, норми и очекиваних животних устројстава.

Љубав је делатна моћ човека, моћ која руши зидове који га раздвајају од ближњих, која га уједињује са другима; љубав му омогућава да превазиђе осећај изолације и издвојености, а ипак му допушта да буде свој, да задржи свој интегритет. У љубави се догађа парадокс да два бића постану једно, а ипак остају два (Фром 1990: 32).

Пре но што завршимо анализу текста приповетке потребно је истаћи два јако битна елемента књижевног дела. Након што Илија, пребачен у будућност без своје воље, у својеврсној конфузији и очају покушава да 
одузме себи живот, поново ће се сусрести са Бранком. У овом моменту истичу се речи мртвог упућене живоме: „Ти си човек!.. Ти мораш све поднети, што ти је усуд усудио!” (Веселиновић 1927: 158). Остаје питање на шта се конкретно мисли. Ситуација у којој се нашао Илија од самог почетка до краја не може се узети као немотивисана. Он је постао својеврсни носилац трагичке кривице. Прво је морао да се избори са губитком и болом, затим са наметнутим идентитетом и улогом, а потом са прелазом из живота у смрт, па са „баченошћу” у будућност. Није ли целокупни ,усуд” претешко бреме за једног младића? Бранку је свирепо одузет живот, а Илија још теже осуђен да прође Голготу живота и смрти, садашњице и будућности.

Други важан аспект текста је графички одвојен коментар. Веселиновићев приповедач, како у овом, тако и другим делима, често на самом почетку или на самом крају пребацује на „другостопену дијагезу” - за њега то није догођена стварност већ испричана прича (в. Вукићевић 2011: 143-165). „Топла је рука старе баке; слатка су сећања на детињство, кад су нас оваквим лепим причама успављивали...” (Веселиновић 1927: 161). Аутор као да је желео да се огради од самог текста и тиме је, по нашем мишљењу, нарушио савршенство дела. Одвојени коментар не само да није логичан, већ одступа од остатка текста. И, наравно, поставља питања: Зашто бака успављује децу причама са хорор елементима, без срећног краја? Чини се да је намена коментара/пасуса искључиво била у сврху ограђивања од концизно изложене грађе испод које смо копали и дошли до „провокативних закључака”. Као да је судбина која је додељена јунацима приповетке и завршница дела био једини могући начин да се удовољи јавном мњењу, тј. очекивањима тадашње публике.

Овај рад сагледава приповетку Вечност Јанка Веселиновића из новог угла. Интерпункција и приповедање, временска и просторна измештеност, мали број сведених реакција главних јунака узели смо као показатеље покушаја да се нешто прећути/сакрије или боље рећи не да на очиглед. Дакле, побратимство је у приповетки Вечност својеврсни криптограм испод кога се могу тумачити скривена значења. Пошли смо од претпоставке да писац као припадник патријархалне средине и времена није могао бити упознат са одређеним концептима идентитета, што не значи да те концепте није могао уметнички обрадити и изложити у свом делу у мери која је била прикладна/дозвољена времену у ком је писао. Напор да ништа из света интимног/скривеног не открије, јер нема статус прихваћеног и друштвеном нормом и очекивањем прописаног, писац је на особен начин уобличио у криптограмско рухо. 
Виђење изнето у овом раду представља један од могућих видова тумачења наизглед конкретне и једнозначне, али свакако неисцрпне грађе која је уткана у Веселиновићево дело. Аутор нуди своје гледиште као једно, не и једино, са циљем да укаже на естетску провокативност и модерност текста.

\section{ЛИТЕРАТУРА}

Барјактаревић 1992: М. Барјактаревић, Неки ранији облищи „сродства" код нас, у: Прилози за књижевност, језик, историју и фолклор, Београд: Филолошки факултет.

Библија или Свето писмо Старога и Новога завјета, Београд: Југословенско библијско друштво, 2001.

Ван Генеп 2005: А. Ван Генеп, Обреди прелаза, Системско изучавање ритуала, Београд: Српска књижевна задруга.

Веселиновић 1927: Ј. Веселиновић, Слике из сеоског живота, Београд: Српска књижевна задруга.

Вукићевић 2011: Д. Вукићевић, Анархија текста, Београд: Службени гласник.

Вукићевић 2003: Д. Вукићевић, Огледи о српском реализму, Краљево: Народна библиотека „Стефан Првовенчани”.

Деретић 2004: J. Деретић, Историја српске књижевности, Београд: Просвета.

Николић 2013: Н. Николић, Гласник етнографског музеја, књ. 78, Београд: Етнографски музеј.

Пековић 2006: С. Пековић, Зборник радова Јанко Веселиновић, Проза, периодика, позориште, Београд: Институт за књижевност и уметност.

Росић 2008: Т. Росић, Теорије и политике рода, Родни идентитет у књижевностима и културама југоисточне Европе, Београд: Институт за књижевност и уметност.

Скерлић 1967: Ј. Скерлић, Историја нове српске књижевности, Београд: Просвета.

Стефановић Караџић 1987: В. Караџић Стефановић, Српски рјечник, Београд: Просвета.

Ћопић 2008: Х. Ћопић, Жене и језик, у: H. B. Stiftung, Неко је рекао феминизам?, Београд: Регионална канцеларија за Југоисточну Европу.

Филиповић 1963: С. Филиповић, Јанко Веселиновић. Београд: Нолит.

Фром 1990: Е. Фром, Умеће љубави, Београд: BIGZ.

Чајкановић 1994: В. Чајкановић, Студије из српске религије и фолклора 1910-1924. Београд: Српска књижевна задруга. 
Vladimir D. Janković

\section{ALLIANCE ${ }^{4}$ AS CRYPTOGRAPHIC CODE IN JANKO VESELINOVIĆ'S SHORT STORY VEČNOST (ETERNITY)}

\section{Summary}

In this work the topic wich will be disscused is short story Večnost (Eternity) written by Janko Veselinović. We will try to interpretate this story using some points of view wich haven't been considered in literature science so far. At first, we will analise structural elements of text, such as punctuation, narative forms and behaviour of main characters. We'll try to expand the field of our research on themes and motives not specifically represented by the author. Alliance as the main motiv of this work represents example of cryptogram, whose interpretation will lead us to the hidden meanings. Author offers us one of the possible forms of interpretation, that can be used as a starting point for future research of this topic.

Key words: alliance motive, cryptogram, identity, publicly and privately, realism short story

${ }^{4}$ Except for this words the words "fraternity" and "brotherhood" can be used, but the suggested term is the most suitable one for the topic in question. 